\title{
The Implementation of Regulation of the Minister of Education and Culture Number 23 Year 2015 Concerning Character Development in the Middle School
}

\author{
Siti Awaliyah*, Rosyid Al Atok, Nisa A'rafiyah Tri Wulandari \\ Jurusan Hukum dan Kewarganegaraan \\ Universitas Negeri Malang \\ Malang, Indonesia \\ *siti.awaliyah.fis@um.ac.id
}

\begin{abstract}
This paper discuss about character development activities in the middle school (junior and senior high school), the responsible parties, and the obstacles encountered in character education. The descriptive method was used shows that character development activities consist of: 5S habit (smile, greeting, greet, handshake, polite), creation of a clean and green environment, improvement of faith and devotion, singing national songs, reading habits, praying in congregation, flag ceremonies and anniversaries of the national day, collection and distribution of charity, activities to commemorate religious holidays, development of student potential, peer tutors, and the orientation of new pupils; the parties involved are the head master, teachers, employees, pupils, parents/guardians, and the surrounding community; and obstacles encountered are communication between the parties and the motivation of the pupils. Upon these results, Regulation of The Minister of Education and Culture Number 23 Year 2015 Concerning Character Development in The Middle School have been implemented well. And there are three differences of implementation character education between Indonesia and America.
\end{abstract}

Keywords-character development; character education; habituation; regulation of the minister of education and culture no.23 of 2015

\section{INTRODUCTION}

Mahatma Gandhi said that there are seven deadly sins. They are spreading values and behavior for acquiring wealth without work, pleasure without conscience, knowledge without character, business without morality, science without humanity, religion without sacrifice and politics without principle [1]. Today, that phenomenon has plagued most of society in the world [2]. In the school area, brawling between students, violence and bullying are risky problem [3] that can be prevented by character education [4]. Prevention and treatment should be carried out more intensively to the teenagers who are the future generation of Indonesia. Building god-fearing, noble, spirit of patriotic and nationalism character is very important for them because they affect the survival of nation [5].

Education has a very important role in developing character of nation's next generation because education has two great goals: to help people become smart (intellect) and to help people become good (character) [6]. Debriefing various fields in schools is needed by pupils. Building good and noble character related with Pancasila's values is one of the aims of implementation of education.

Government, in particular Ministerial of Education and Culture which is responsible for the maintenance of the level of education in elementary and middle schools issued regulations related the obligation of the school to develop good character. The detailed provisions are set out in the Regulation of the Minister of Education and Culture of the Republic of Indonesia No.23 of 2015 About Character Development on July 13, 2015 [7].

Philosophically, ideal aims in the regulations are listed in the consideration that school should be a comfortable and inspiring place for students, teachers and educational staff. For that, attitudes and positive behaviors habituation in schools should reflect the values of Pancasila. Pancasila' values should be part of the process of learning and culture in schools.

The implementation methods of character development are adjusted to the school's conditions. Some of those mentioned in this regulations is about purpose, the parties involved, and monitoring and evaluation strategy. In regulation also set a mandatory activity that are still very common. Its developed depends on each school culture.

According to those reasons, author interested to discuss concerning the implementation of the regulations, in middle school (junior and senior/vocational high school). The study related to (1) activities development for character developing in junior and senior /vocational high school, (2) the parties involved in the character development activities in junior and senior/vocational high school, and (3) obstacles and efforts to face difficulties in character development in junior and senior/vocational school.

\section{METHODS}

This study is a qualitative research, with case study approach [8]. This research is focused on attempts to describe 
the development carried out by the school related to the mandate to grow the moral character of students in school.

The study was conducted in junior and senior high school in Malang, located in State Junior High School 6 Malang, State Junior High School 10 Malang, State Senior High School 5 Malang, and Vocational School PGRI 2 Malang. Data resources in the study consisted of primary data resources and secondary data resources. The primary data resources is composed of: headmasters, teachers, staff, and pupils. Secondary data resources are Regulation of The Minister of Education and Culture Number 23 Year 2015 concerning Character Development, activities reports, and books. Data collection is done by observation, interviews, and documentation [7].

Analyzing data is done from field data collection activities until the end of the activities. In this study, researchers used two types of data analysis techniques that are domain analysis and taxonomic analysis techniques [9]. Domain analysis is used to obtain a description or definition generally and relatively through focus or subject matter being studied. Then, results domain analysis is used as starting point to the more detailed and deeper issues, that taxonomic analysis to be useful to describe or explain the focus of research. Taxonomic analysis is a follow up after data display generally, are discussed more detailed and deeper in every issue.

\section{RESULTS AND DISCUSSION}

In Indonesia, character development in school is influenced by the condition of the school, creativity of teachers and conditions of pupils so that every school have different forms of activities performed character development. Although, the aims of the implementation of character development is rather the same, to achieve the vision of each school who aspire to grow up the next generation which is excellent and having environmental thought based on science and technology and faith and devotion.

The middle school in Malang has implemented various activities to develop good character integratedly with learning in or outside class activities. During school, since pupils arrive in school in the morning until learning was done in the afternoon, school try to grow up a good attitudes. Some of the activities in the development character program are: (1) $5 \mathrm{~S}$ habit, (2) creation of clean and green environment, (3) improvement of faith and devotion, (4) singing national songs, (5) reading habits, (6) praying in congregation,(7) flag ceremonies and anniversaries of the national holiday, (8) collection and distribution of charity, (9) activities to commemorate religious holidays, (10) development of student potential, (11) peer tutors, (12) orientation of new pupils , (13) parents meeting, and (14) graduation activities.

Based on above data display, at least can be seen three important things. First, the Government of the Republic of Indonesia in this case the Ministry of Education and Culture has been carrying out its duties in taking responsibility for education in elementary and middle school by issuing Regulation of the Minister of Education and Culture of the Republic of Indonesia Number 23 Year 2015 Concerning Character Development, set on 13 July 2015 to grow up noble character for the next generation. Procedurally, the Ministry of Education and Culture informed the regulation through socialiszation to the Regional Office of the Ministry of Education and Culture and Department of Education District/City. In this research, it is known that Malang Department of Education has instructed all schools in Malang for implementing character development through circular letter. So it can be said that the entire elementary and middle schools located in the autonomous region in Indonesia, both in the provincial and district/city including Malang mandatory and has been carrying out the character development [7].

Based on the study above it can be seen that character development is a form of character education in Indonesia. In the English Literature, the term character education can be represented by some of the terms that is character building, character development, character education, character traits, moral education and others [10]. Scerenko found character education can be interpreted as an earnest effort to develop positive personality, encourage and empower by examplary, study (history and biographies of the sages and great thinkers), and practice of emulation (a maximum effort to realize the wisdom of what is observed and studied) [11]. Thus, character education is to grow good character. According to Lickona, character is composed of active value, and it is constituted by values that can be seen through one's behavior [6]; [12]. Characters are intimately associated with person behavior. Lee concluded that a person of good character is a morally mature person with equal development in moral judgment, moral emotion, and moral behavior [12].

The implementation of character education in Indonesia has differences with the character education undertaken in the United State. US Federal Government, in this case the Departments of Education in the US mandates that character education is important to be implemented [13]. Unlike in Indonesia, the US Federal Government has not issued regulations governing procedures for the implementation of character education for the entire school over the United States. In The United State the implementation of character education is very dependent on the policy of each state or each school. Nonetheless, the US Federal Government grants education reaches 1,000,000 US Dollars for the State Educational Agencies and Local Educational Agencies in each state of America to work together in making implementation design of character education program. The grant is regulated in the Improving America's Shool Act of 1994 in Chapter X Part A of Section 10103 of the Partnerships in Character Education Pilot Project.

Since 1995, there are 36 states that have earned the grant [13]. Of the 36 states that receive grants, there are 10 states (Alabama, Arkansas, California, Florida, Georgia, Indiana, Nebraska, Tennese, Uttah, and Virginia) who has made a rule about character education in his state, and there are 7 states (Maryland, Mississippi, North Carolina, Oklahoma, Oregon, Washington and West Virginia) that still make rules regarding character education [13]. Thus, it can be said that the states in America, autonomously can make their own rules about character education to be implemented in their state without the intervention of the Federal State. 
Implementation of character education in America's schools can be considered by organizations that focus on character education studies, such as the organization named character.org, Character Count, Character Education Partnership etc [14]. For explanation, Character.org is an organization formed by people who are passionate and dedicated itself in developing character education so they can help community, peoples, schools, parents and even pupils for optimal results in character education. Character.org which is currently led by Linda McKay, National Advocate Character Education in America's Schools believes that education is the key to transform the character of a nation becoming more compassionate nation. Change.org formulated had 11 principles in implementing effective character education [15]. The eleven principles are promoting core values; defines "character" to include thinking, feeling, and doing; uses a comprehensive, approach; creates a caring community; provides students with opportunities for moral action; offers a meaningful and challenging academic curriculum; fosters students' self-motivation; Engages staff as a learning community; fosters shared leadership; Engages families and community members as partners; assesses the culture and climate of the school. Through his book, A Framework for School Success 11 Principles of Effective Character Education, character.org explain the principles, indicators implementation until evaluating system that can be used by schools in implementing effective character education. So schools in the United States can use such books as one of the guides in developing character education.

Those are the differences between regulations issued by the Government of Indonesia and the United States related to the implementation of character education. In Indonesian schools in the provincial level and at the district/city as an autonomous region is required to conduct character development by Regulation of The Minister of Education and Culture Number 23 Year 2015 concerning character development. While in America, states as autonomous regions have the right to make or not make the rules relating to the implementation of character education [7].

Second result of the research is each school implement activities forms of character development already based on Regulation of the Minister of Education No.23 of 2015 concerning character development [7]. The activities forms of character have reflected seven habituation activities listed in Appendix Regulation of The Minister of Education and Culture Number 23 Year 2015 concerning character development. They are habituation to develop moral and spiritual values that is reflected in the increase of faith and devotion which was implemented in nearly every morning in schools. It is also reflected in the congregation prayer activities required for all students, activities in the religious holidays, and other activities.

Almost the same as in Indonesia, schools in the United States that implement character education, implementation is also carried out in an integrated manner in the classroom and outside the classroom. Based on the results of research sponsored by the US Department of Education 2010, produced research findings that character education is more appropriately carried out in schools by using collaborative and experiential teaching method and learning pro-social activities such as cooperative learning, conflict resolution, service learning, campaigns against bullying [16]. So it can be said that character education in schools in America are integrated in the learning undertaken by using teaching pro social activities such as service learning so that students have the experience to do a service to the community, with the aim to raise pupils awareness (caring). To support the success of character education, schools in the United States is also seeking to establish the creation of a positive interaction between pupils and teachers, class meetings effectively, building community, positive interactions between pupils, presenting a good role model, democratic student organizations, cooperative learning, resolution conflict, and service learning [16]. In addition, the activities that are often carried out by schools in the United States is visiting museum with the aim to foster nationalism and follow good manners of heroes, doing moral discussion with the teacher before or after school to foster teamwork and togetherness [13]. Thus, it can be concluded that there is little difference between character education undertaken in Indonesia and in the United States. The difference is activities form of character development.

Related with the values instilled in pupils, there is a significant difference between character education in Indonesia and in the United States. In Indonesia, the values inculcated in the pupils stated clearly on Regulation of The Minister of Education and Culture Number 23 Year 2015 concerning character development as it is written above. While in America, the values instilled in pupils depend on character education program that was designed by each state or each school because there is no national regulation contained values which must be taught. For example, during the years 19992000 at Westside Elementary, in Cedartown, Georgia implanted 30 worth of character development. While in Cedar Hill Middle School, Suzan Brown made a list of characters that need to be instilled covering cheerfulnes, citizenship, cleanliness, compassion, cooperation, courage, courtesy, creativity, dependability, diligence, fairness, generosity, helpfulness, honesty, joyfulness, kindness, loyalty, patience, perseverance, punctuality, respect, respect for the environment, responsibility, school pride, self-control, sportsmanship, tolerance [13]. Different from Suzan Brown, school which is initiated by Character Counts should implement character education with Six Pillars of Character (trustworthiness, respect, responsibility, fairness, caring, and citizenship) [13]. Based on above exposures, there are differences in the values that are grown in character education in Indonesia and in the United States. In comparison, the values of which are grown in Indonesia not only be based humanity values but also grounded in religious values. While in America tend to be based on humanity values only.

For succeeding character development activities, it is much needed cooperation from various parties. There are eight (8) parties that play a role in character development activities. They are (1) the principal, (2) the vice principal, (3) religious teacher and Pancasila and Citizenship Education teacher, (4) disciplinary and student affairs team, (5) Adiwiyata team, (6) all subject teachers, (7) parents, and (8) community. 
So, it can be concluded that parents, teachers and school employees, and society contribute to the implementation of character development program [2]. In connection with the parties that play a role, there is little difference with those who act in character education in America. In America, in addition to parents, teachers and school employees, and the public, there are others who contribute in implementing character education. Other parties are organizations that care about character education in America like Character Count, Texas Buliding Character, The Character Education Partnership and other organizations [13]. The contribution made by these organizations include making character education program that can be adopted by schools that will, provide information related to character education in America through the website, etc.

In character development there are obstacles that be faced by each school. Obstacles was encountered by school was almost the same between one school with another school. Following this study, there are (2) constraints faced by schools in implementing character development.

First obstacle is problem of communication. School as place of interaction between the school community that consists of various status, character and personality do not always run in line with the applicable rules. Sometimes, language which has function as a tool of communication between people sometimes was misunderstood by the school community because they are less listened to or less understand the language submitted. This leads to communication problems (misscomunication) and misconceptions (miss understanding). Both of these cause the activities carried out by the students become constrained.

Second obstacle is disorder of pupils. School as a place to study would have many pupils. Many pupils are naturally derived from different living environments and have different customs. So, there are differences between habits at home and around the house with the customs environment in the school. This case resulted character development program in school becomes impeded. From this research, to be known that students as the main target of character development is less able to follow the activities implemented in the schools because the differences of their habits and living environment with school's habit. This is proven by pupils who are still breaking the rules, such as defacing plants in the school, scribbling on school facilities, coming late, unfollow the activities as they should be etc.

Efforts are being made to overcome these constraints are imposing sanctions and by a dialogue. When pupils break the rules or undisciplined, school through disciplinary team can impose sanctions according to their violation. Besides sanctioned, parties that involved faced the problems by doing dialogue for problem solving. So, the obstacles can be solved properly. If the dialogue conducted by the school and students did not find a way out then the school will call the parents to find the best solution. With the holding of dialogue in kinship, the school hopes that problems that occur can be resolved properly so the character development activities can implement optimally and is not constrained.

\section{CONCLUSION}

Regulation of The Minister of Education and Culture Number 23 Year 2015 Concerning Character Development in The Middle School have been implemented well. Junior and senior/vocational high school in Malang have been implemented various activities to develop good character integratedly with learning in or outside class activities. And there are three differences of implementation character education between Indonesia and America. First, the methods for growing up good characters. Second, values instilled in pupils. Third, the parties who involved in character education.

\section{REFERENCES}

[1] D. Budimansyah, Penguatan Pendidikan Kewarganegaraan untuk Membangun Karakter Bangsa. Widya Aksara Press. Bandung, 2010.

[2] N. Temis, "An Example of 'Character Education' Course Design in the Light of Éxperienced Centred' Design for Higher Education," Journal of Education and Practice, vol. 7, no.36, pp. 144-155, 2016.

[3] S. Waters, and N. Mashburn, "An Investigation of Middle School Teachers' Perceptions on Bullying," Journal of Social Studies Education Research, vol. 8, no. 1, pp. 1-34, 2017.

[4] K. Lake, “Character Education from A Children's Rights Perspective: An Examination of Elementary Students' Perspectives and Experiences," International Journal of Children's Rights, vol. 19, no. 4, pp. 679-690, 2011.

[5] A. Altikulac and O. Sabanci, "Nationalism Perceptions of Pre-Service Social Studies Teachers in Turkey," Journal of Education and Practice, vol. 8, no. 8, 2017.

[6] T. Lickona, "Preparing teachers to be moral educators: A neglected duty," New Directions for Higher Education, vol. 1980, no. 31, pp. 5164, 1980.

[7] Republik Indonesia, Peraturan Menteri Pendidikan dan Kebudayaan No.23 Tahun 2015 Tentang Penumbuhan Budi Pekerti. Lembaran Negara Republik Indonesia Tahun 2016 Nomor 897, 2015.

[8] W.C John, Penelitian Kualitatif dan Desain Riset (Memilih diantara lima pendekatan), Diterjemahkan oleh Ahmad Lintang Lazuardi. Jakarta: Pustaka Pelajar, 2003.

[9] S. Faisal, Penelitian Kualitatif Dasar-dasar dan Aplikasi, Malang:YA3, 1980.

[10] A. Taylor, Character Education: a Bibliography of Recent Research, Reports and Resources, Slough: NFER, 2017.

[11] M. Samani and Hariyanto, Konsep dan Model Pendidikan Karakter, Bandung: PT Remaja Rosdakarya, 2013.

[12] I.N.J. Lee, Moral and Character Education Methods and Character Education Program Based On Experiences. In Handbook of Moral and Character Education, Nucci, Larry dkk (ed). New York: Routledge, 2014.

[13] S.L. McElmeel, Character Education A Book Guide for Theachers, Librarians, and Parents, Colorado. Teacher Ideas Press: A Division of Greenwood Publishing Group, Inc, 2002.

[14] P.L. Glanzer and A.J. "Milson, Legislating the Good A Survey and Evaluation of Character Education Laws in the United States," Educational Policy, vol. 20, no. 3, pp. 525-550, 2006.

[15] Character.org., A Framework for School Success 11 Principles of Effective Character Education, Retrieved from: www.character.org Accesed 11 January 2018, 2014.

[16] R.J. Sojourner, "The Rebirth and Retooling of Character Education in America," Retreived from: www.mcgraw-hillresearchfoundation, Accesed 24 January 2016, 2012. 